\title{
PHENOTYPIC AND MOLECULAR CHARACTERIZATION OF Salmonella Enteritidis STRAINS ISOLATED IN SÃO PAULO, BRAZIL
}

\author{
Sueli A. FERNANDES(1), Ângela C.R. GHILARDI(1), Ana T. TAVECHIO(1), Antonia M.O. MACHADO(2) \& Antonio C.C. PIGNATARI(3)
}

\begin{abstract}
SUMMARY
In São Paulo State, Brazil, the epidemic increase in isolation of Salmonella Enteritidis has been observed since 1994. A total of 105 S. Enteritidis strains (72 from human and 33 from non-human sources) isolated during the period 1975-1995, previously characterized by phage typing, was analyzed by antimicrobial susceptibility, plasmid profile, and ribotyping. Over $70 \%$ of the strains were susceptible to all antimicrobial agents tested, however, multiple resistance to antimicrobials was observed among the studied strains, mainly those from hospitalized patients. Phage type 8 (PT-8) was predominant among the strains isolated during the period of 1975-1992, but in the following years, PT-4 was the most frequent phage type identified. Seven different plasmid profiles were detected and $96 \%$ of the isolates harbored a plasmid of approximately $36 \mathrm{MDa}$. Ribotyping discriminated fourteen ribotypes (R1 to R14) among the strains examined. By analysis of dendrogram the strains were included in three groups with similarity level of $60 \%$. The obtained results indicate that, a single ribotype (R11), determined for PT-4 strains isolated from 1993, characterizes the epidemic clone of $S$. Enteritidis in our region.
\end{abstract}

KEYWORDS: Salmonella Enteritidis; Antimicrobial resistance; Phagetypes; Plasmids; Ribotypes.

\section{INTRODUCTION}

During the past decade, Salmonella enterica subsp. enterica serotype Enteritidis ( $S$. Enteritidis) infections in humans have become an established problem not only in developing countries but also in developed ones. Since the 80 's, there has been a dramatic increase in the number of reported findings of this serotype in Europe and worldwide ${ }^{3,9,11,19,21}$.

In São Paulo State, Brazil, the remarkable increase in the incidence of human $S$. Enteritidis isolates began to be noticed in 1993. Since 1994, it has become the most frequent serotype responsible for foodborne outbreaks and sporadic cases of human gastrointestinal diseases. It has also been observed an increase of $S$. Enteritidis isolated from blood cultures mainly in children and patients with immunodeficiency syndrome $e^{14,22}$.

The increased prevalence of $S$. Enteritidis infections in humans has often been associated with the consumption of eggs, foods that contain raw eggs, poultry meat, and other poultry products contaminated with S. Enteritidis ${ }^{22}$.

The detection of chains of infections requires methods that should be able to discriminate $S$. Enteritidis strains isolated from different sources. For the effective epidemiological studies, traditional and molecular methods have been applied for $S$. Enteritidis ${ }^{4,5,8,9,10,17}$.
The purpose of this study was to investigate by antimicrobial resistance, plasmid profiling, and the rRNA gene restriction pattern (ribotyping) the relatedness of $S$. Enteritidis strains isolated in our geographic area, during the period from1975 to 1995.

\section{MATERIAL AND METHODS}

Bacterial strains: A total of $105 \mathrm{~S}$. Enteritidis strains isolated in different geographic locations from S. Paulo State were studied: 46 were selected from seventeen outbreaks ( 39 were from enteritis cases and seven from egg-based foods, identified as the vehicle of infection in seven outbreaks); 33 strains were from sporadic cases (22 isolated from stool, 10 from blood, and one from urine). Furthermore, 15 isolates from egg-containing foods, nine from poultry, and two from sewage were included. The strains had been isolated at the Central and Regional Public Health Laboratories, Hospital Laboratories, Laboratories of Animal Pathology and Food Microbiology of São Paulo Universities between 1975 and 1995. All strains were serotyped according to POPOFF \& LE MINOR ${ }^{15}$ at the Laboratory of Enteric Pathogens, Instituto Adolfo Lutz. They were stored on nutrient agar, at room temperature. These $S$ Enteritidis strains were previously characterized by phage typing ${ }^{6}$ by using the system described by WARD et al. ${ }^{27}$, with 10 typing phages obtained from the International Reference Laboratory for Enteric Phage Typing, Colindale, London, U.K. (Table 1). 


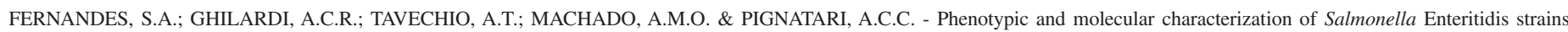
isolated in São Paulo, Brazil. Rev. Inst. Med. trop. S. Paulo, 45(2):59-63, 2003.

Table 1

Phage types of $S$. Enteritidis from human and non-human sources isolated between 1975-1995, in São Paulo, Brazil

\begin{tabular}{lccccr}
\hline \multicolumn{5}{c}{ Number (\%) of strains isolated in } \\
Phage type & $1975-1992$ & 1993 & 1994 & 1995 & Total \\
\hline PT-2 & $1(4.0)$ & & & & $1(0.9)$ \\
PT-4 & $1(4.0)$ & $2(40.0)$ & $25(96)$ & $47(95.9)$ & $75(71.5)$ \\
PT-6 & & & & $1(2.0)$ & $1(0.9)$ \\
PT-8 & $19(76.0)$ & $2(40.0)$ & $1(4)$ & $1(2.0)$ & $23(21.9)$ \\
PT-22 & $2(8.0)$ & & & & $2(1.9)$ \\
PT-23 & $1(4.0)$ & & & & $1(0.9)$ \\
UT* & $1(4.0)$ & $1(20.0)$ & & & $2(1.9)$ \\
TOTAL & 25 & 5 & 26 & 49 & 105 \\
\hline
\end{tabular}

*Untypeable (UT), strains with no reactions with any of the ten typing phages.

Antimicrobial susceptibility testing: The antimicrobial susceptibility assays were performed by the standard disc diffusion method on Mueller-Hinton agar, as described in the NCCLS guidelines ${ }^{13}$. The following disc antibiotics and the respective concentration, purchased from CECON, were included: ampicillin (AMP), $10 \mu \mathrm{g}$; cefoperazone (CFP), $75 \mu \mathrm{g}$; ceftazidime (CAZ), $30 \mu \mathrm{g}$; cephalothin (CEF), $30 \mu \mathrm{g}$; chloramphenicol (CHL), $30 \mu \mathrm{g}$; ciprofloxacin (CIP), $5 \mu \mathrm{g}$; gentamicin $(\mathrm{GEN}), 10 \mu \mathrm{g}$; kanamycin (KAN), $30 \mu \mathrm{g}$; nalidixic acid (NAL), $30 \mu \mathrm{g}$; streptomycin (STR), $10 \mu \mathrm{g}$; sulfonamide (SSS), $300 \mu \mathrm{g}$; tetracycline (TET), $30 \mu \mathrm{g}$; trimethoprim-sulfamethoxazole (SXT), $25 \mu \mathrm{g}$.

Plasmid DNA analysis: Plasmid DNA of each strain was extracted and purified according to $\mathrm{KADO} \& \mathrm{LIU}^{7}$. Samples were analyzed by electrophoresis in $1 \mathrm{X}$ Tris-acetate buffer at $100 \mathrm{~V}$ for $3 \mathrm{~h}$ on $0.8 \%$ horizontal agarose gel. Plasmids of 60 and $36 \mathrm{MDa}$, and lambda DNA HindIII digest were run as molecular weight standards.

Ribotyping: Chromosomal DNA of all strains was extracted and purified according to BRENNER et al. ${ }^{2}$. From preliminary findings ${ }^{10}$ $S p h \mathrm{I}$ was selected for ribotyping of the strains and DNA was digested according to the reaction conditions recommended by the manufacturer (Pharmacia, LKB). DNA fragments were analyzed in horizontal electrophoresis on $0.8 \%$ agarose gel (Sigma) in Tris-acetate EDTA as running buffer. A Haemophilus aegyptius 3031 EcoRI DNA digest (fragment sizes: 17613, 6334, 5575, 4960, 3789, 3228, 1713, 1497 bp) was used as molecular marker. The restriction fragments were transferred under vacuum (Vacugene, Pharmacia, LKB) to nylon membranes and hybridized with the $16 \mathrm{~S}+23 \mathrm{~S}$ cDNA probe transcribed by reverse transcriptase from E. coli rRNA (Boerhinger Mannheim, Germany) and labeled with digoxigenin according to POPOVIC et al. ${ }^{16}$. Computerassisted analysis of ribotyping patterns was done by using Gel Compar II software, version 1.5 (Applied Mathas, Kortrijk, Belgium). The Dice coefficient was used to calculate the similarity coefficients and cluster analysis was performed by using the unweighted pair group method with the arithmetic average methods (UPGMA).

\section{RESULTS}

Antimicrobial susceptibility: The findings obtained in the antimicrobial susceptibility assays (Table 2) showed the following results: $66.7 \%$ of the $S$. Enteritidis strains were susceptible to all antimicrobials tested, $24.8 \%$ presented a single type of resistance, and $8.5 \%$ were multiresistant (two to nine antimicrobials) by nine patterns. All isolates were susceptible to ceftazidime, cefoperazone and ciprofloxacin, more than $90 \%$ were susceptible to ampicillin, cephalothin, chloramphenicol, gentamicin, nalidixic acid and trimethoprim-sulfamethoxazole.

Plasmid analysis: A total of seven different plasmid profiles was seen among $S$. Enteritidis isolates (Fig. 1). The majority (93.3\%) carried

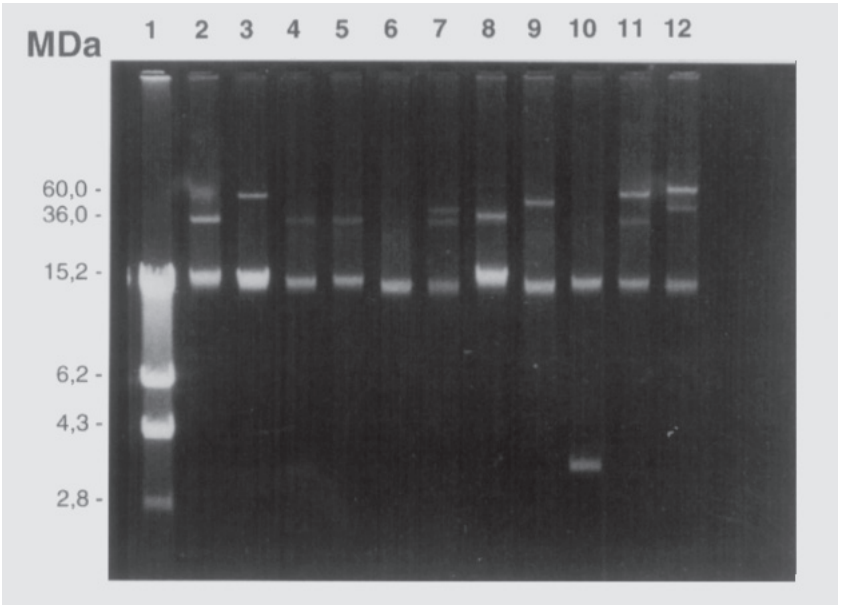

Fig. 1- Plasmid profile of $S$. Enteritidis strains. Lane 1, lambda DNA-HindIII digest; lane 2, E. coli HB101 (36MDa plasmid); lane 3, $S$. Typhimurium C5 (60MDa plasmid); lanes 4, 5 and 8, S. Enteritidis 36MDa plasmid profile; lane 6, plasmid-free $S$. Enteritidis; lane 7, $S$. Enteritidis 34; 38MDa profile; lane 9, S. Enteritidis 50MDa profile; lane 10, S. Enteritidis 2.9MDa profile; lane 11, S. Enteritidis, 36; 60MDa profile and lane 12, S. Enteritidis 38; $65 \mathrm{MDa}$ profile.

Table 2

Antimicrobial resistance of $S$. Enteritidis strains by source of isolate

\begin{tabular}{lccccccccccc}
\hline & & \multicolumn{5}{c}{ Resistance to antimicrobial agent* $(\%)$} \\
\cline { 3 - 11 } Source & Number of strains & NAL & AMP & CEF & CHL & STR & GEN & KAN & SSS & SXT & TET \\
\hline Human & 72 & 3.0 & 6.0 & 3.0 & 3.0 & 18.0 & 2.0 & 10.0 & 13.0 & 4.0 & 14.0 \\
Non-human & 33 & 6.0 & 3.0 & 0 & 3.0 & 6.0 & 0 & 3.0 & 12.0 & 0 & 9.0 \\
\hline
\end{tabular}

* NAL, nalidixic acid; AMP, ampicillin; CEF, cephalothin; CHL, chloramphenicol; GEN, gentamicin; KAN, kanamycin; STR, streptomycin; SSS, sulfonamide; SXT, trimethoprim-sulfamethoxazole; TET, tetracycline. 
a plasmid of approximately $36 \mathrm{MDa}$ and in three strains $(2.8 \%)$ was found a plasmid of approximately $60 \mathrm{MDa}$. It was detected five plasmid free $S$. Enteritidis strains $(4.7 \%)$.

Ribotyping: The number of fragments hybridizing with the probe for rRNA genes ranged from 8 to 10 . The different ribotypes observed differed either in band of high molecular weight (between 15 and 30 $\mathrm{Kbp}$ ) or in the presence of single, double, or triple band at a position corresponding to the $6.3 \mathrm{Kbp}$ marker. A single difference in the number or sizes of bands hybridizing with the probe for rRNA genes was scored as a different rDNA pattern. After $S p h$ I digestion, 14 ribotypes designated R1 to R14 were detected among the $105 \mathrm{~S}$. Enteritidis strains (Fig. 2). The resulting dendrogram (Fig. 3) shows, at a similarity level of $60 \%$, three distinct groups named I, II, and III.

Table 3 shows the correlation between phage types and ribotypes of the $S$. Enteritidis strains. It was observed discrimination of ribotypes

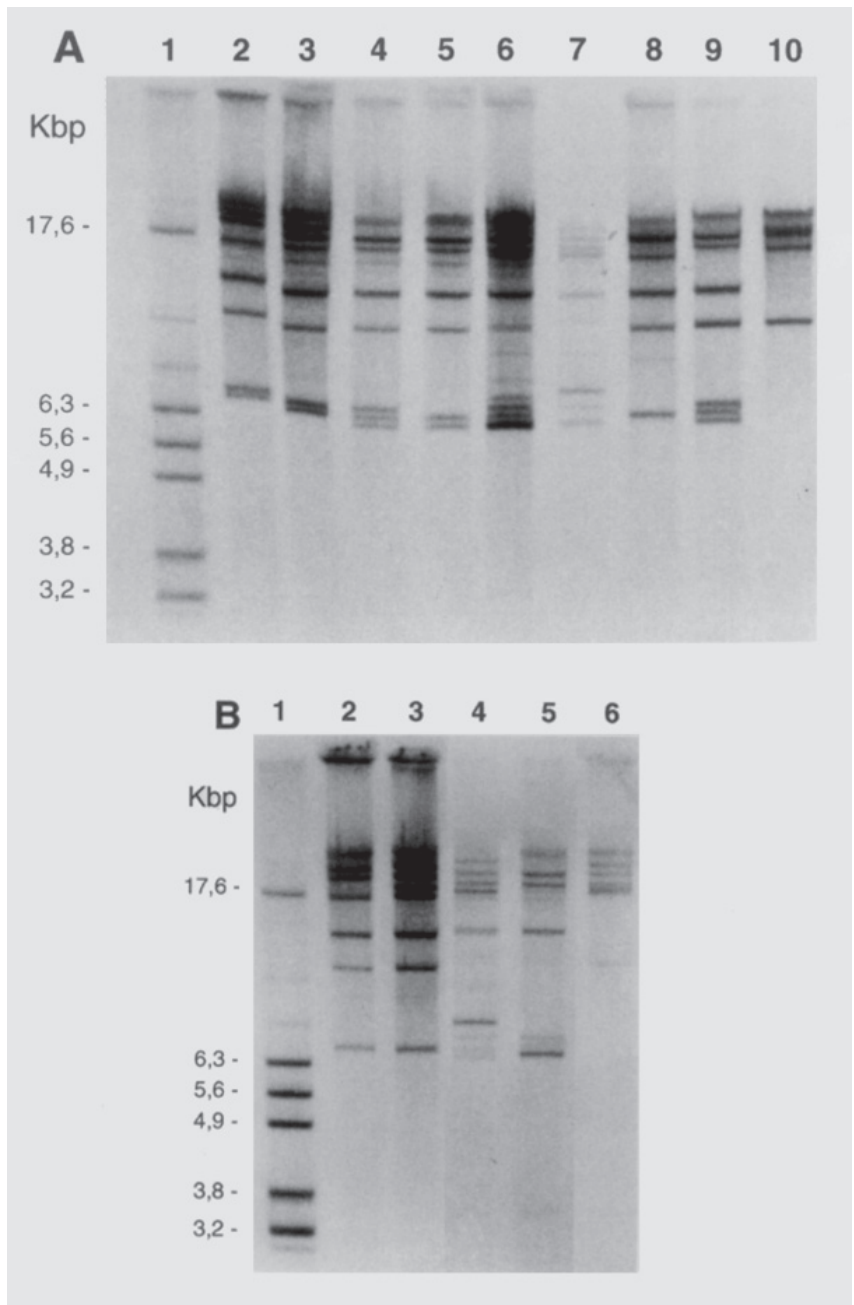

Fig. 2- Ribotypes observed among $S$. Enteritidis strains after hybridization with DIG labeled 16+23S cDNA. A: lane 1, size marker (H. aegyptius 3031 EcoRI digest); lanes 2 to 10 , ribotypes designated R1 to R9 respectively. B: lane 1, molecular weight; lanes 2 to 6, rybotypes $\mathrm{R} 10$ to $\mathrm{R} 14$ respectively.

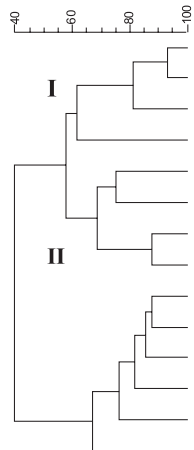

III

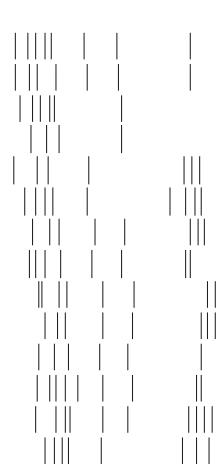

R1
R11
R10
R14
R9
R13
R12
R8
R1
R4
R3
R7
R2
R5
R6
Number of Strains

69

5

Fig. 3- Dendrogram showing similarities among the ribotypes (RT) characterized for $S$. Enteritidis strains.

among the strains belonging to different phage types. Three ribotypes were identified among $S$. Enterititdis PT-4 strains, assigning $72 \%$ of the samples, and other six ribotypes among the PT- 8 strains.

\section{DISCUSSION}

As $S$. Enteritidis infections continue to increase in Brazil, serotype alone becomes less effective as an epidemiological marker, so phenotypic methods used in combination with genotypic ones could be sufficiently discriminatory to differentiate the $S$. Enteritidis strains.

In the present study, our findings indicate that most strains were susceptible to a wide range of antimicrobial agents, confirming earlier data $^{3,9}$. According to Table 2, it was observed a significant resistance among strains isolated from human infections. It was also detected that all multidrug resistance strains were isolated from hospitalized patients. Although most of the isolates in this study were susceptible, active monitoring of $S$. Enteritidis strains for antimicrobial resistance seems to be crucial because of the public health implications of a potential spread of resistant clones ${ }^{12,21}$.

Phage typing provides a rapid and reliable method to discriminate $S$. Enteritidis in epidemiological studies and has been widely used ${ }^{6,17,18,26}$. Among the $105 \mathrm{~S}$. Enteritidis strains previously analyzed, eight phage types (PTs) were detected (Table 1). PT-8 was the predominating phage type identified among the isolates from 1975 to 1992, accounting for $64.0 \%$ of them. Striking change in phage type patterns was seen in 1993 when PT- 4 accounted for $40.0 \%$ of all isolates. In the following years, the progression of PT- 4 is remarkable, remaining the most frequent among the phage typed $S$. Enteritidis strains. The increase of $S$. Enteritidis in our State, since 1993, is clearly related to the progression of PT-4 strains, and almost all strains isolated from sporadic cases, as well as, from outbreaks were associated with this phage type. This predominance among human and non-human sources has shown its wide dissemination in our area ${ }^{6}$.

In the United States, the phage types most commonly associated with human outbreaks of $S$. Enteritidis are PT-8, PT-13a, and PT-13,18,24. $S$. Enteritidis PT-4 had remained very rare in the United States and when isolated, was associated with foreign travel. However, two outbreaks of this strain that occurred in the Chinese restaurant El Paso, Texas, in 1993, 


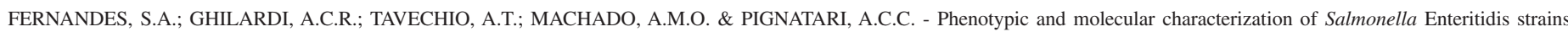
isolated in São Paulo, Brazil. Rev. Inst. Med. trop. S. Paulo, 45(2):59-63, 2003.

caused by contaminated egg rolls, seemed to introduce this phage type in that area. In 1995 in the state of Utah, $S$. Enteritidis caused fivefold increase in human infections, which were transmitted by eggs from a single farm and the isolates were identified as PT-4 $4^{1,20}$. In Europe, PT-4 has emerged as the predominant phage type, spreading rapidly through both poultry and human populations and replacing all other phage types ${ }^{3,5,11}$.

Although phage typing has been helpful for subdividing $S$. Enteritidis strains from different sources, the method has proved to be insufficiently discriminatory when only one phage type has predominated, making necessary additional characterization.

Plasmid profiling is a traditional method used for epidemiological purposes in Salmonella strains within specific serotypes. In the present study, we isolated a $36 \mathrm{MDa}$ plasmid from almost all strains and the frequency of other plasmids was very low (Fig. 1). It was observed that the latter plasmids were detected mostly in the multiresistant strains. However, further studies would be necessary to know if the resistance was attributed to those plasmids.

Our data indicate that there are multiple phage types within a single plasmid profile. On this basis, it is clear that plasmid profile typing is not as discriminatory as phage typing for the primary subdivision of this serotype. Due to its ubiquitous feature, the $36 \mathrm{MDa}$ plasmid did not show any epidemiological importance, as reported in previous studies for $S$. Enteritidis S $^{4,9,10,18,24,25}$.

The use of ribotyping as an epidemiological tool in assessing the relatedness of outbreak related strains and sporadic ones of $S$. Enteritidis has been reported by several researchers ${ }^{4,8,11,17,23}$.

In the present study, ribotyping has successfully differentiated strains within the phage types of $S$. Enteritidis. Strains belonging to PTs 6, 22, 23 , and two untypeable strains were associated to specific ribotypes. Moreover, six ribotypes were identified within PT-8 and three in PT-4 strains, as seen in Table 3.

Indeed, PT-8 ribotypes R8 and R2 appear to characterize most of strains circulating during the earliest years of "pre-epidemic" period (1975-1992). We observed high degree of homogeneity among the strains isolated after 1993, since only two ribotypes were identified (R11, R14). Such data suggest that there is limited number of types or clonal lines, of which only one (R11) was widely disseminated. The epidemiological aspects of circulation of $S$. Enteritidis in different geographic areas of S. Paulo State, in the period considered, may be interpreted on the basis of these findings.

The PT-4 ribotype R11 in the "epidemic" period was increasingly detected among non-human and non-outbreak strains, and it was also involved in the majority of foodborne outbreaks occurring in the years 1993-1995 as the predominating clone, accounting for $86.25 \%$ of $S$. Enteritidis strains studied in this period.

Analyzing the dendrogram (Fig. 3) we observed that these strains were included in the group I, which also included the ribotype R14 associated with five isolates from two foodborne outbreaks. In the group III was classified the ribotype R7 representing the single PT-4 strain isolated before 1993 from human infection. The results obtained correlate well with those of previous studies described by other authors ${ }^{8,9}$.
Table 3

Correlation between phage types and ribotypes of the $S$. Enteritidis strains

\begin{tabular}{ccl}
\hline Phage type & No. of strains & Ribotype (No. of strains) \\
\hline 8 & 23 & R1 (1); R2 (12); R3 (3); \\
R8 (5); R9 (1); R13 (1) \\
4 & 75 & R7 (1); R11 (69); R14 (5) \\
2 & 1 & R2 (1) \\
6 & 1 & R10 (1) \\
22 & 2 & R4 (2) \\
23 & 1 & R5 (1) \\
UT $^{*}$ & 2 & R6 (1); R12 (1) \\
\hline
\end{tabular}

*Untypeable (UT), strains with no reaction with any of the ten typing phages.

In our experience, ribotyping is a genomic profiling method, which is reproducible and adequate to evaluate relatedness and to trace the spread of $S$. Enteritidis under study, revealing a homogeneous clonal structure in contemporary PT-4 isolates.

\section{RESUMO}

\section{Caracterização fenotípica e molecular de cepas de Salmonella Enteritidis isoladas em São Paulo, Brasil}

A ocorrência de $S$. Enteritidis, no Estado de São Paulo, Brasil, tem aumentado acentuadamente desde 1994. Um total de 105 cepas de $S$. Enteritidis (72 de origem humana e 33 de fontes não humanas), isoladas durante o período 1975-1995, previamente caracterizadas por fagotipagem, foram analisadas para: susceptibilidade aos antimicrobianos, perfil plasmidial e ribotipagem. Aproximadamente $70 \%$ das cepas foram susceptíveis aos agentes antimicrobianos testados, porém multirresistência foi principalmente observada, entre aquelas cepas isoladas de pacientes hospitalizados. No período de 1975-1992 verificouse o predomínio do fagotipo 8 (PT-8), porém, nos anos seguintes, PT-4 foi o fagotipo predominante. Sete diferentes perfis plasmidiais foram detectados e $96 \%$ das cepas albergavam um plasmídio de aproximadamente $36 \mathrm{MDa}$. A ribotipagem discriminou 14 ribotipos (R1 a R14) entre as cepas examinadas. Pela análise do dendrograma, as cepas foram incluídas em três grupos com nível de similaridade de $60 \%$. Os resultados obtidos indicam que um único ribotipo (R11), determinado para as cepas PT-4 isoladas a partir de 1993, caracteriza o clone epidêmico de $S$. Enteritidis em nossa região.

\section{REFERENCES}

1. BOYCE, T.G.; KOO, D.; SWERDLOW, D.L. et al. - Recurrent outbreaks of Salmonella Enteritidis infections in a Texas restaurant: phage type 4 arrives in the United States. Epidem. Infect., 117: 29-34, 1996. 

isolated in São Paulo, Brazil. Rev. Inst. Med. trop. S. Paulo, 45(2):59-63, 2003.

2. BRENNER, D.J.; MCWHORTER, A.C.; KNUTSON, J.K.L. \& STIEGERWALT, A.G. Escherichia vulneris: a new species of Enterobacteriaceae associated with human wounds. J. clin. Microbiol., 15: 1133-1140, 1982.

3. FANTASIA, M. \& FILETICI, E. - Salmonella enteritidis in Italy. Int. J. Food Microbiol., 21: 7-13, 1994.

4. GONZALEZ-HEVIA, M.A. \& MENDOZA, M.C. - Polymorphism of rRNA genes and plasmid analysis in the typing of Salmonella enterica serovar enteritidis from a Spanish health area. New Microbiol., 18: 377-384, 1995.

5. HICKMAN-BRENNER, F.W.; STUBBS, A.D. \& FARMER III, J.J. - Phage typing of Salmonella enteritidis in the United States. J. clin. Microbiol., 29: 2817-2823, 1991.

6. IRINO, K.; FERNANDES, S.A.; TAVECHIO, A.T.; NEVES, B.C. \& DIAS, A.M.G. Progression of Salmonella Enteritidis phage type 4 strains in São Paulo State, Brazil. Rev. Inst. Med. trop. S. Paulo, 38: 193-196, 1996.

7. KADO, C.I. \& LIU, S.T. - Rapid procedure for detection and isolation of large and small plasmids. J. Bact., 145: 1365-1373, 1981.

8. LANDERAS, E.; GONZÁLEZ-HEVIA, M.A.; ALZUGARAY, R. \& MENDOZA, M.C - Epidemiological differentiation of pathogenic strains of Salmonella enteritidis by ribotyping. J. clin. Microbiol., 34: 2294-2296, 1996.

9. LING, J.M.; KOO, I.C.; KAM, K.M. \& CHENG, A.F. - Antimicrobial susceptibilities and molecular epidemiology of Salmonella enterica serotype Enteritidis strains isolated in Hong Kong from 1986 to 1996. J. clin. Microbiol., 36: 1693-1699, 1998.

10. MARTINETTI, G. \& ALTWEGG, M. - rRNA gene restriction patterns and plasmid analysis as a tool for typing Salmonella enteritidis. Res. Microbiol., 141: 1151$1162,1990$.

11. NASTASI, A. \& MAMMINA, C. - Epidemiology of Salmonella enterica serotype Enteritidis infections in southern Italy during the years 1980-1994. Res. Microbiol., 147: 393-403, 1996.

12. NASTASI, A.; MAMMINA, C. \& CANNOVA, L. - Antimicrobial resistance in Salmonella Enteritidis, Southern Italy, 1990-1998. Emerg. infect. Dis., 6: 401-403, 2000.

13. NATIONAL COMMITTEE FOR CLINICAL LABORATORY STANDARDS - Methods for dilution antimicrobial susceptibility tests for bacteria that grow aerobically. 5. ed. Wayne, National Committee for Clinical Laboratory Standards, 2001. (Approved standard M2-A7).

14. PERESI, J.T.M.; ALMEIDA, I.A.Z.C.; LIMA, S.I. et al. - Surtos de enfermidades transmitidas por alimentos causados por Salmonella Enteritidis. Rev. Saúde públ. (S. Paulo), 32: 477-483, 1998.
15. POPOFF, M.Y. \& LE MINOR, L. - Formules antigéniques des sérovars de Salmonella. Paris, Centre Collaborateur OMS de Référence et de Recherche pour les Salmonella, 1997.

16. POPOVIC, T.; BOPP, C.A.; OLSVIK, O. \& WACHSMUTH, K. - Epidemiologic application of a standardized ribotype scheme for Vibrio cholerae 01. J. clin. Microbiol., 31: 2474-2482, 1993.

17. RIDLEY, A.M.; THRELFALL, E.J. \& ROWE, B. - Genotypic characterization of Salmonella enteritidis phage types by plasmid analysis, ribotyping, and pulsed-field gel electrophoresis. J. clin. Microbiol., 36: 2314-2321, 1998.

18. RODRIGUE, D.C.; CAMERON, D.N.; PUHR, N.D. et al. - Comparison of plasmid profiles, phage types, and antimicrobial resistance patterns of Salmonella enteritidis isolates in the United States. J. clin. Microbiol., 30: 854-857, 1992.

19. RODRIGUE, D.C.; TAUXE, R.V. \& ROWE, B. - International increase in Salmonella Enteritidis: a new pandemic? Epidem. Infect., 105: 21-27, 1990.

20. SOBEL, J.; HIRSHFELD, A.B.; McTIGUE, K. et al. - The pandemic of Salmonella enteritidis phage type 4 reaches Utah: a complex investigation confirms the need for continuing rigorous control measures. Epidem. Infect., 125: 1-8, 2000.

21. TASSIOS, P.T.; MARKOGIANNAKIS, A.; VATOPOULOS, A.C. et al. - Molecular epidemiology of antibiotic resistance of Salmonella enteritidis during a 7-year period in Greece. J. clin. Microbiol., 35: 1316-1321, 1997.

22. TAVECHIO, A.T.; FERNANDES, S.A.; NEVES, B.C.; DIAS, A.M.G. \& IRINO, K. Changing patterns of Salmonella serovars: increase of Salmonella Enteritidis in São Paulo, Brazil. Rev. Inst. Med. trop. S. Paulo, 38: 315-322, 1996.

23. THONG, K.L.; NGEOW, Y.F.; ALTWEGG, M.; NAVARATNAM, P. \& PANG, T. Molecular analysis of Salmonella enteritidis by pulsed-field gel electrophoresis and ribotyping. J. clin. Microbiol., 33: 1070-1074, 1995.

24. THRELFALL, E.J. \& CHART, H. - Interrelationships between strains of Salmonella enteritidis. Epidem. Infect., 111: 1-8, 1993.

25. THRELFALL, E.J.; ROWE, B. \& WARD, L.R. - Subdivision of Salmonella enteritidis phage types by plasmid profile typing. Epidem. Infect., 102: 459-465, 1989.

26. USERA, M.A.; POPOVIC, T.; BOPP, C.A. \& STROCKBINE, A. - Molecular subtyping of Salmonella enteritidis phage type 8 strains from the United States. J. clin. Microbiol., 32: 194-198, 1994.

27. WARD, L.R.; de SA, J.D.H. \& ROWE, B. - A phage-typing scheme for Salmonella enteritidis. Epidem. Infect., 99: 291-294, 1987.

Received: 16 September 2002

Accepted: 17 March 2003 